\title{
Macrophytes in the assessment of river ecological condition on the example of Pszczynka River (Silesian Upland)
}

\author{
Edyta Sierka $^{1}$, Agnieszka Tomczak ${ }^{1}$ \\ 1Department of Geobotany and Nature Conservation, Faculty of Biology and Environmental Protection, University of Silesia, \\ Jagiellońska Str. 28, 40-032 Katowice, Poland \\ E-mail address (corresponding author): edyta.sierka@us.edu.pl
}

\begin{abstract}
The Water Framework Directive introduced an ecological approach to the assessment and classification of waters. The part of the assessmentare macrophyte - based methods used in the evaluation of the ecologicalcondition of rivers in respect of biodiversity. The Macrophyte Method for River Assessment has been used in Poland since 2007 and provides us with an information about ecological state of the rivers. Presented analyses were aimed to describe macrophyte development in the sandylowland type of river in the Silesian Upland. The assessment was made for lowland Pszczynka River (45.8 km total length, total catchment area $368.3 \mathrm{~km}^{2}$ ), which is a left-bank tributary of Vistula River. At the selected 10 research sections of the river (100 m each) the composition of macrophytes and abiotic conditions of the river were described. The paper presents the results of preliminary assessment of ecological condition of Pszczynka River on the background sources of substances discharged to the riveralongits course. Macrophyte Index for Rivers (MIR) was calculated based on the results of the research - river bed surface coverage by the particular plant species. The MIR limit values were used to determine the class of water quality in the examined river. Overall, the ecological status of Pszczynka River was rated as moderate and its water classified as Class III of water quality.
\end{abstract}

KEY WORDS: macrophytes, bioidication, Water Framework Directive, monitoring

\section{Introduction}

Regulations of the Water Framework Directive (Directive 2000/60/EC), establish framework for Community actions in the field of sustainable water policy in Europe. Furthermore, the document introduces a requirement to assess water quality by identifying the ecological condition of aquatic ecosystems using biological criteria. Macrophytes are one of the four basic elements in the assessment of the ecological condition of rivers in addition to phytoplankton, macrozoobenthos and fish fauna (GEBLER \& SzOSZKIEWICZ, 2011). The group of macrophytes includes vascular plants, aquatic bryophytes and algae producing macroscopic thalli (JANAUER, 2001). The species composition of these plants presents high specificity, which depends on the prevailing habitat conditions. Macrophyte Method of River Assessment is also used to determine the degree of nutrient content in the water (HAURY ET AL., 2006) and is based on the characteristics of aquatic vegetation in the analysed section of the river within its homogeneous fragment. The species composition and amount of vegetation are a response to the prevailing ecological conditions (Bus, 2010). The aim of this study was to present ecological condition of one of the rivers in the Upper Silesia, which remained under the influence of diverse land use, by Macrophyte Method of River Assessment taking into account existing sources of nutrient inflow.

\section{Study area}

The study area is located in the Silesian voivodeship (southern Poland), in the Pawłowice commune. The springs of the Pszczynka River are located at an altitude of $270 \mathrm{~m}$ a.s.l. in the mesoregion 
of the Silesian Upland called Rybnik Plateau (KoNDRACKI, 2002). The Pszczynka River cuts through the villages Warszowice and Krzyżowice. Their surface is slightly folded with ground level differences reaching $25 \mathrm{~m}$. The highest peak is located at an altitude of $285 \mathrm{~m}$ a.s.l., while the lowest point at $233 \mathrm{~m}$ a.s.l. It is connected with the erosion and mining activities in the area. There are deposits of coal and methane situated as the accompanying resources exploited within one of the two mining areas, namely "Krzyżowice III" associated with the coal mine "Pniówek". Thus, the landscape presents typical for the industrial landscape post-mining waste dumping grounds, subsidence troughs and discontinuous deformations, occurring in the northern part of the community.

The soils occurring in the analysed area of the community are mainly specific brown, leached brown and pseudo-podzol. The valleys of the rivers are filled with fluvial mud, sand, gravel, as well as silty-swamp, peat and muck soils. The predominant type of soils in the Pawłowice community, concerning their agricultural properties, are of average quality or anthropogenic soils, mainly within the intensively industrialised areas.

\subsection{Pszczynka River}

The Pszczynka River, one of the major rivers in the area, flows in the embankment elevated sometimes to several meters above the ground level (PROGNOZA ODDZIAŁYWANIA NA ŚRODOWISKO..., 2010) (Fig. 1). Pszczynka is the sandy lowland type of river. It was created as a way to minimize the socalled mining damage. What is more, the river bed was also partly artificially altered. Total length of the river is $45.8 \mathrm{~km}$, and it is accompanied by numerous fish ponds. The Pszczynka catchment covers an area of $368.3 \mathrm{~km}^{2}$. Pumping stations were built on both sides of the river in order to prevent floods (STELMASZCZYK, 2007). Pszczynka River cuts mainly agricultural and urbanised areas. Scanty riparian ash-alder (Fraxino-Alnetum) and willow (Salicetum albo-fragilis) forests accompanied by their early stage of succession: riverine wickers (Salicetum triandro-viminalis) occur in this area (CZAUDERNA, 2011).

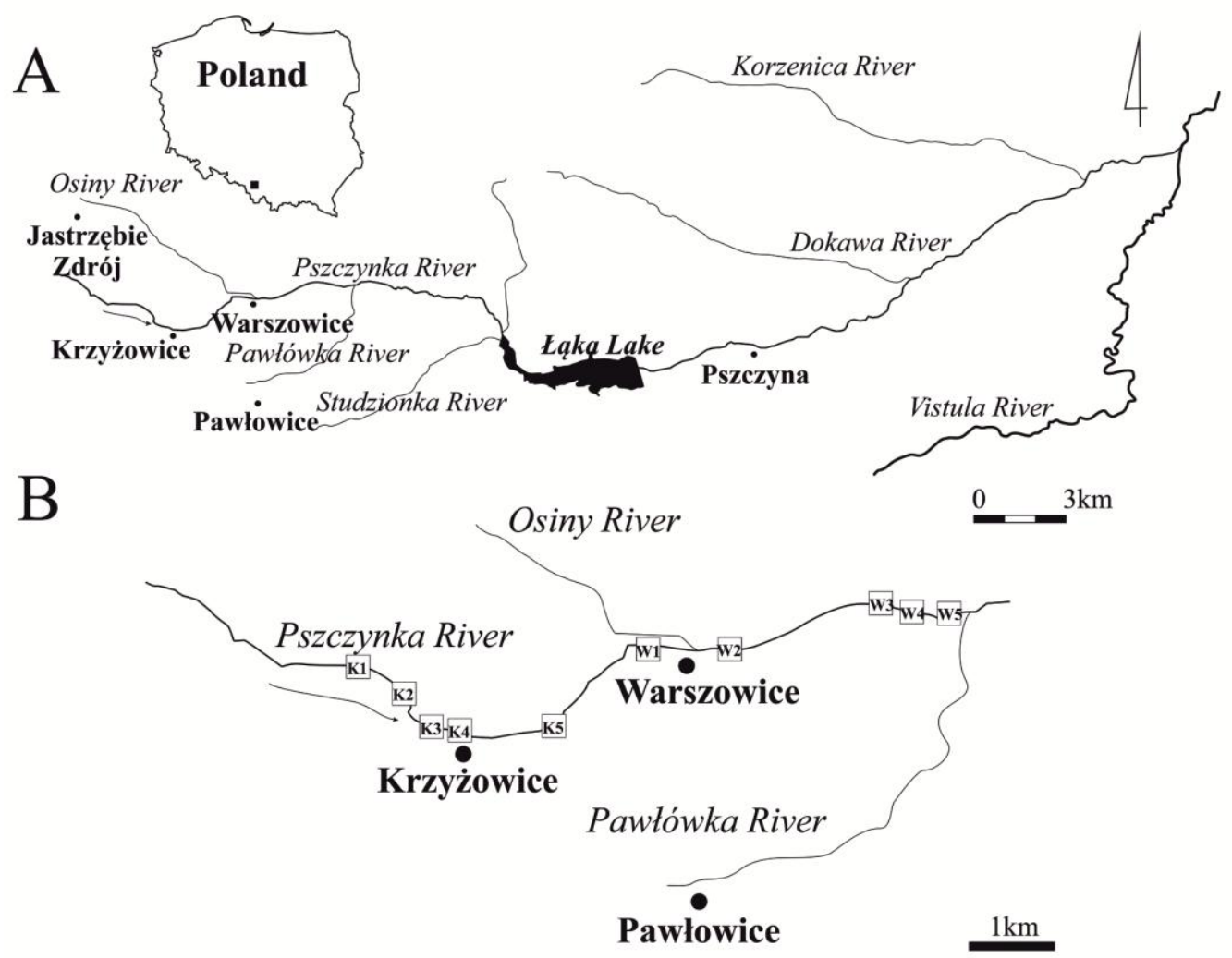

Fig. 1. Location of study area (A) and sampling sites along the Pszczynka River (B) in the area of Pawłowice community

The main right-bank tributaries in this fragment are Pawłówka and Studzionka, while the leftbank are the channel Branicki and Osiny stream. The research carried out over the past years indicated that water shows periodically increased mineralisation of $1.1-3.5$ g.l-1. These waters are in contact with water discharges from the mining region (PROGNOZA ODDZIAEYWANIA NA ŚRODOWISKO, 2010). 


\section{Materials and methods}

Macrophyte surveys were conducted between July and September 2012 year according to the Macrophyte Method for River Assessment methodology. Macrophyte Method for River Assessment has been used since 2007 and provide us information about ecological state of rivers. The botanical research was based on the Polish method used in the national monitoring based on the Macrophyte Index for Rivers (MIR) (SzoszkIEWICZ ET AL., 2010). It involves quantitative and qualitative inventory of all species growing in the 100-meter reach of a river according to nine-point scale (Tab. 1).

Polish method uses a Macrophyte Index for Rivers - MIR, which is calculated by summing the products of each of species cover value (P), weight index (W) and species trophic rank (L) and then dividing these by the product of weight index and species cover value for scoring species. The weight index shows taxon tolerance and assigns a value from 1 to 3 for the least tolerant taxa. The species trophic rank depends on tolerance to eutrophic waters and its scale has ten points from 1 for the most tolerant species.

The research sections were located in the Pawłowice commune (Pszczyński District), there were 5 sections in Krzyżowice village (K1-K5) and the same number in Warszowice (W1-W5) (Fig. 1). The list of research sections together with the coordinates and their location was presented in Table 2.

Table 1. The scale of the degree of the bottom coverage by macrophytes (after: Szoszkiewicz et al., 2010)

\begin{tabular}{|l|r|c|c|c|c|c|c|c|c|}
\hline $\begin{array}{l}\text { Percentage share in coverage } \\
{[\%]}\end{array}$ & $<0.1$ & $0.1-1$ & $1-2.5$ & $2.5-5$ & $5-10$ & $10-25$ & $25-50$ & $50-75$ & $>75$ \\
\hline Coefficient of coverage & 1 & 2 & 3 & 4 & 5 & 6 & 7 & 8 & 9 \\
\hline
\end{tabular}

Table 2. Description of abiotic conditions at the research section (author's research)

\begin{tabular}{|c|c|c|c|c|c|c|}
\hline \multirow[b]{2}{*}{ Village } & \multirow[b]{2}{*}{$\begin{array}{l}\text { Research } \\
\text { section }\end{array}$} & \multirow[b]{2}{*}{ Coordinates } & \multicolumn{4}{|c|}{ Elements of river's environmental } \\
\hline & & & $\begin{array}{l}\text { Range of value: } \\
\text { river width }(\mathrm{m}) \\
\text { river depth }(\mathrm{m})\end{array}$ & $\begin{array}{c}\text { Shadow } \\
(\%)\end{array}$ & $\begin{array}{c}\text { River bed } \\
\text { modifications }\end{array}$ & Dominant plant species \\
\hline \multirow{5}{*}{ 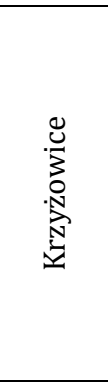 } & $\mathrm{K} 1$ & $\begin{array}{l}495919 \mathrm{~N} ; \\
183949 \mathrm{E}\end{array}$ & $\begin{array}{c}1-5 \\
0.25-0.5\end{array}$ & 50 & $\begin{array}{l}\text { profiling, } \\
\text { firming }\end{array}$ & Phalaris arundinacea \\
\hline & $\mathrm{K} 2$ & $\begin{array}{l}495974 \mathrm{~N} ; \\
184083 \mathrm{E}\end{array}$ & $\begin{array}{c}5-10 \\
0.8-2.1\end{array}$ & 0 & $\begin{array}{l}\text { profiling, } \\
\text { firming }\end{array}$ & Phalaris arundinacea \\
\hline & K3 & $\begin{array}{l}495955 \mathrm{~N} ; \\
184018 \mathrm{E}\end{array}$ & $\begin{array}{c}5-10 \\
0.9-1.8\end{array}$ & 0 & $\begin{array}{l}\text { profiling, } \\
\text { firming }\end{array}$ & Phalaris arundinacea \\
\hline & K4 & $\begin{array}{l}495949 \mathrm{~N} ; \\
184021 \mathrm{E}\end{array}$ & $\begin{array}{c}5-10 \\
1.0-1.7\end{array}$ & 0 & $\begin{array}{l}\text { profiling, } \\
\text { firming }\end{array}$ & Phalaris arundinacea \\
\hline & K5 & $\begin{array}{l}495959 \mathrm{~N} ; \\
184193 \mathrm{E}\end{array}$ & $\begin{array}{c}1-5 \\
0.8-1.0 \\
\end{array}$ & 0 & $\begin{array}{l}\text { profiling, } \\
\text { firming }\end{array}$ & Phalaris arundinacea \\
\hline \multirow{5}{*}{ 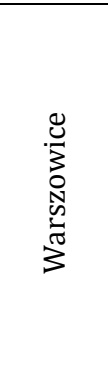 } & W1 & $\begin{array}{l}495935 \mathrm{~N} ; \\
184159 \mathrm{E}\end{array}$ & $\begin{array}{c}1-5 \\
0.5-1\end{array}$ & 20 & $\begin{array}{l}\text { profiling, } \\
\text { firming }\end{array}$ & Ceratophyllum demersum \\
\hline & W2 & $\begin{array}{l}495938 \mathrm{~N} ; \\
184391 \mathrm{E}\end{array}$ & $\begin{array}{c}1-5 \\
0.6-1.2\end{array}$ & 0 & profiling & Zanichellia palustris \\
\hline & W3 & $\begin{array}{l}495954 \mathrm{~N} ; \\
184443 \mathrm{E}\end{array}$ & $\begin{array}{l}1-5.5 \\
0.5-1\end{array}$ & 0 & profiling & Zanichellia palustris \\
\hline & W4 & $\begin{array}{l}495949 \mathrm{~N} ; \\
184527 \mathrm{E}\end{array}$ & $\begin{array}{c}1-6 \\
0.5-1 \\
\end{array}$ & 0 & profiling & Phalaris arundinacea \\
\hline & W5 & $\begin{array}{l}495953 \mathrm{~N} ; \\
184524 \mathrm{E}\end{array}$ & $\begin{array}{c}1-5 \\
0.4-1.3\end{array}$ & 0 & profiling & Phalaris arundinacea \\
\hline
\end{tabular}

Table 3. Macrophyte Index for Rivers values for sandy type of river (after: Szoszkiewicz et al., 2010

\begin{tabular}{|c|c|c|c|}
\hline No. & Ecological status class & Lowland river sandy and organic & Quality class of water \\
\hline 1 & Very good & $\geq 44.5$ & I \\
\hline 2 & Good & $44.5-35.0>$ & II \\
\hline 3 & Moderate & $35.0-25.4>$ & IV \\
\hline 4 & Poor & $25.4-15.8>$ & V \\
\hline 5 & Bad & $\leq 15.8$ & \\
\hline
\end{tabular}


Macrophyte Index for Rivers (MIR) was calculated based on the results of the research (river bed surface coverage by the particular plant species) and the values of L and W (SzOSZKIEWICZ ET AL., 2010) with the following formula:

$$
\mathrm{MIR}=\frac{\sum_{i=1}^{n}\left(L_{i} \cdot W_{i} \cdot P\right)_{i}}{\sum_{i=1}^{n}\left(W_{i} \cdot P_{i}\right)} \cdot 10
$$

where:

$M I R$ - value of the Macrophyte Index for Rivers at the sampling site, $N$ - number of species at the sampling site;

$\mathrm{Pi}$ - ratio of coverage for the $i$-th taxon;

$W i$ - weighting factor for the $i$-th taxon;

$\mathrm{Li}$ - indicator value for the $i$-th taxon (SzOSZKIEWICZ ET AL., 2010)

\section{Results}

The total number of 33 plant species (min. 6, max. 13) was recorded during the field research on the analysed sections of the river. They were
The lower the MIR value, the more degraded the watercourse in terms of trophic status. MIR values range from 10 for eutrophic rivers to up to 100 for rivers with the best ecological status. The MIR limit values were used to determine the class of water quality in the examined river, which were assigned to the 5 classes of water quality for the type of lowland sand and organic rivers (SZOSZKIEWICZ ET AL., 2010) (Tab. 3.).

Based on the data collected in the field, in addition to the MIR index, macrophyte metrics were calculated, i.e., the number of species and number of indicator species. The names of plant species and communities were given after MIREK ET AL. (2002).

Table 4. Macrophytes species occurred in the each of the research sections (author's research)

\begin{tabular}{|c|c|c|c|c|c|c|c|c|c|c|c|c|}
\hline \multirow{2}{*}{ No } & \multirow[t]{2}{*}{ Species } & \multicolumn{10}{|c|}{ Study section } & \multirow{2}{*}{$\begin{array}{c}\text { Frequency } \\
(\%)\end{array}$} \\
\hline & & K1 & $\mathrm{K} 2$ & K3 & $\mathrm{K} 4$ & $\mathrm{~K} 5$ & W1 & W2 & W3 & W4 & W5 & \\
\hline 1 & Agropyron repens & & & & 1 & & & & & & & 10 \\
\hline 2 & Alisma plantago-aquatica & & & 1 & & 2 & & & & & & 20 \\
\hline 3 & Batrachium aquatile & & & & & 2 & & & & & & 10 \\
\hline 4 & Bidens frondosa & & & 1 & 1 & & & & & & & 20 \\
\hline 5 & Callitriche verna & & 1 & & & & & 3 & 4 & 2 & & 40 \\
\hline 6 & Ceratophyllum demersum & & 1 & & 1 & 1 & 7 & 3 & 1 & 3 & 3 & 80 \\
\hline 7 & Eupatorium cannabinum & 2 & & & & & & & & & & 10 \\
\hline 8 & Glyceria fluitans & 2 & 2 & 1 & 2 & 2 & 2 & & & & & 60 \\
\hline 9 & Glyceria maxima & & & & & & & 1 & 3 & 3 & 3 & 40 \\
\hline 10 & Iris pseudoacorus & & 1 & 2 & & 1 & 1 & & & & & 40 \\
\hline 11 & Juncus conglomeratus & & & 1 & & & & & & & & 10 \\
\hline 12 & Juncus effesus & & 1 & & 1 & & & & & & & 20 \\
\hline 13 & Lemna minor & 3 & 1 & 1 & 1 & 2 & 2 & 1 & 2 & & 1 & 90 \\
\hline 14 & Lycopus europaeus & 1 & & & 1 & & 1 & & & & & 30 \\
\hline 15 & Lysimachia nummularia & & 1 & & 1 & & & & & & & 20 \\
\hline 16 & Lythrum salicaria & & & 1 & 1 & & & & & & & 20 \\
\hline 17 & Oenanthe aquatica & & & & & 1 & & & & & & 10 \\
\hline 18 & Phalaris arundinacea & 4 & 3 & 3 & 3 & 3 & 4 & 6 & 6 & 7 & 5 & 100 \\
\hline 19 & Phragmites australis & & & & & & & & & & 2 & 10 \\
\hline 20 & Poa palustris & & & 3 & 3 & & & & & & & 20 \\
\hline 21 & Polygonum hydropiper & & 1 & 1 & 1 & 3 & & & & & & 40 \\
\hline 22 & Potamogeton crispus & & & 1 & & & & & & & & 10 \\
\hline 23 & Potamogeton natans & & & & & & 1 & 2 & 3 & & & 30 \\
\hline 24 & Ranunculus repens & & 1 & & & & & & & & & 10 \\
\hline 25 & Ranunculus sceleratus & & & & & & 1 & & & & & 10 \\
\hline 26 & Rumex hydrolapathum & & & & & & & & 1 & 1 & 1 & 30 \\
\hline 27 & Rumex palustre & & & 1 & & 1 & & & & & & 20 \\
\hline 28 & Sagittaria sagittifolia & 1 & & & & & & & & & & 10 \\
\hline 29 & Salix alba & 3 & & & & & & & & & & 10 \\
\hline 30 & Scrophularia umbrosa & 1 & & & & & & & & & & 10 \\
\hline 31 & Typha angustifolia & & & 2 & 2 & & & & & & & 20 \\
\hline 32 & Urica dioica & & & & & & & 1 & & & 1 & 20 \\
\hline 33 & Zanichellia palustris & & & & & & 6 & 7 & 7 & 4 & 4 & 50 \\
\hline \multicolumn{2}{|c|}{ Total number of species } & 8 & 10 & 13 & 12 & 11 & 9 & 8 & 8 & 6 & 8 & \\
\hline
\end{tabular}




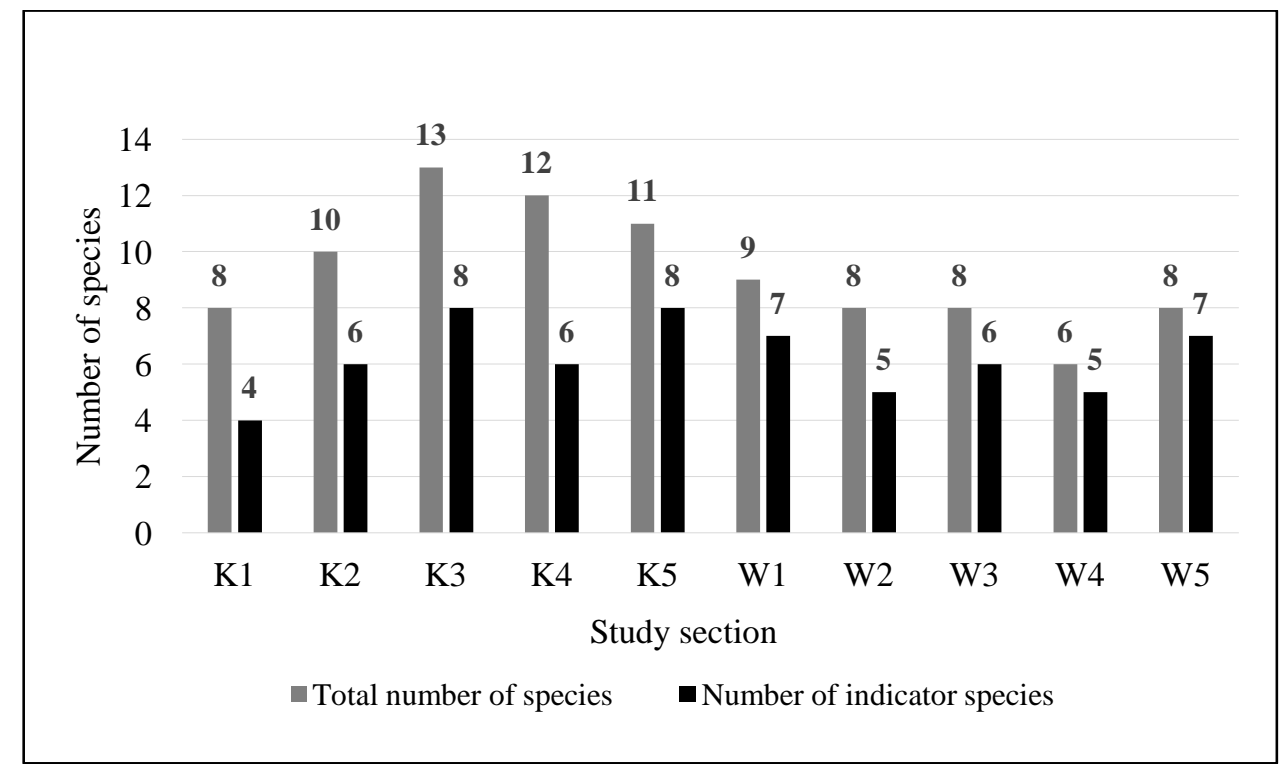

Fig. 2. Participation of macrophyte species in research sections of Pszczynka River (author's research)

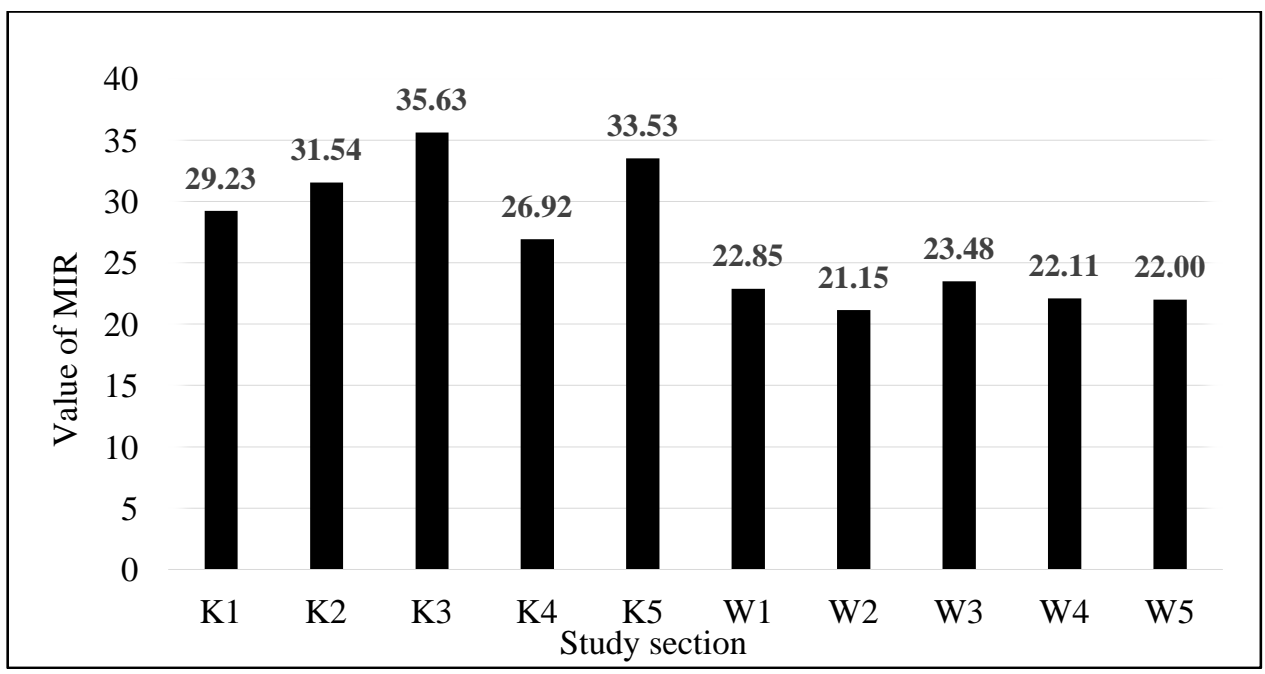

Fig. 3. Macrophyte River Index value in study section of Pszczynka River (author's research)

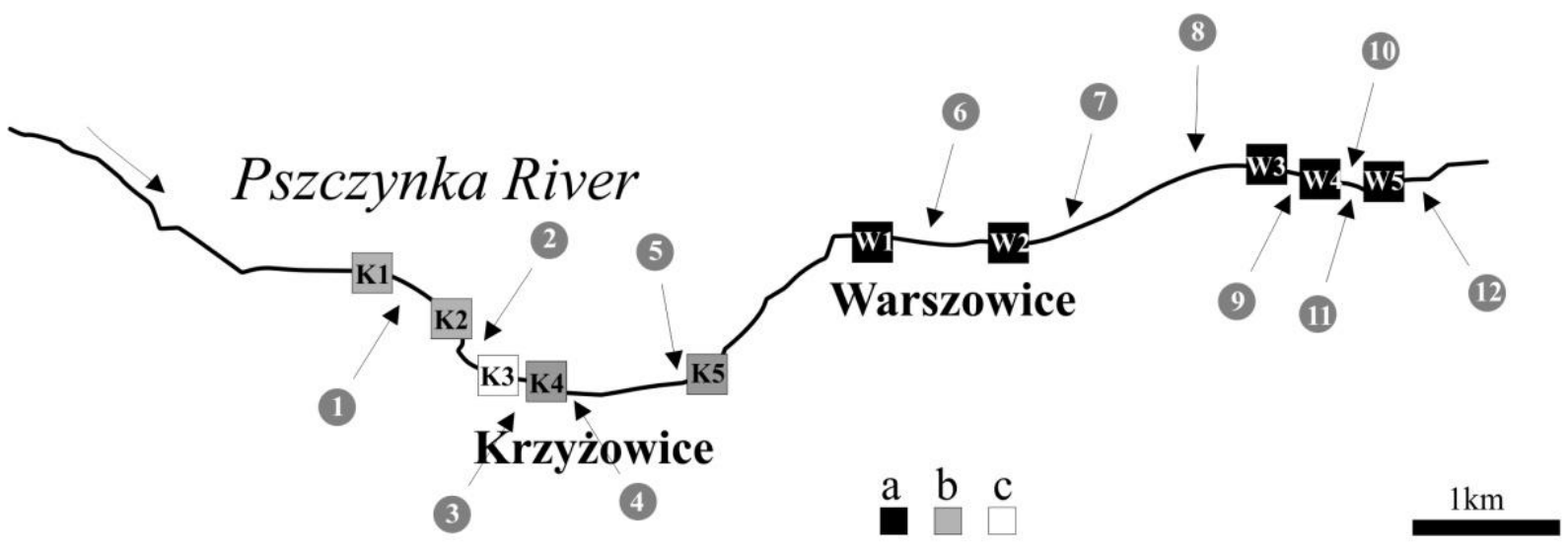

Fig. 4. Pszczynka River and objects affecting its ecological status in the area of Pawłowice community (author's research)

1 - tirbutary of Dębinka stream; 2 - pumping station; 3 - tributary from „Kościelniok” dumping ground; 4 - wastewater treatment plant; 5 - pumping station; 6 - tirbutary of Osiny stream; 7 - tributary; 8, 9, 10,11 - field drainage ditches; 12 - tributary of Pawłówka stream. Ecological status class/ Quality class of water: a - poor/ Class IV; b - moderate/ Class III, c - good/ Class II 
The value of Macrophyte Index for Rivers, based on the calculated values of the indices ranged from 21.15 to 35.62 , on the average for the river reaching 26.84 . The calculated average value of MIR puts it in Class III of ecological condition of water. The Figure 4 show research sections of the river and tributaries of other watercourses, pumping stations, wastewater treatment plants and other objects that affect the Pszczynka River.

\section{Discussion}

The study of the selected Pszczynka River sections in the area of Pawłowice community showed high variability of abiotic conditions among them. The insolation was also diversified. The shading of particular sections was dependent on the time of the day, the density of crowns of the trees covering the river banks and the type of embankments.

The research sections of the river are different concerning plant species composition. The total number of 33 plant species was recorded during the field studies. Similarly to the research by GEBLER \& SZOSZKIEWICZ (2011) performed on lowland rivers the most common species were: Lemna minor and Phalaris arundinacea. Reed canary grass occurred at all of the analysed sections (100\%), while Lemna minor was observed in $90 \%$ of them. Frequently occurring species was also Ceratophyllum demersum that was reported in $80 \%$ of the sections. On average, approximately 9.2 plant species were present at the investigated area of the Pszczynka River. The smallest number of species was recorded in the W4 section. Such low species diversity in this section was most likely caused by extremely large number of reed canary grass, which by covering a large area of the river bed reduced the occurrence of other species. Zanichella palustris is an interesting species occurring in 5 of the sections of the river bed in Warszowice. This species is commonly found in brackish waters. The salt in Pszczynka River probably comes from the streams flowing through the "Kościelniok" post-mining dumping ground situated in Krzyżowice. The mouth of the water discharged from the dumping ground to Pszczynka is located at the border of the two villages.

Indicatory macrophytes constituted $67.4 \%$ of all recorded species, as in GEBLER \& SZOSZKIEWICZ (2011), who in their papers indicated the share of this group from $45 \%$ to $71-79 \%$. The calculated value of the Macrophyte Index for Rivers varied among the particular research sections, which indicated variable water quality in the river.
The analysis of the results showed that one of the directions of variation in lowland rivers is eutrophication and input of pollutants. This is due to the agricultural type of catchment of the studied river sections (GEBLER \& SZOSZKIEWICZ, 2011). Plant species occurring in the river, such as Phalaris arundinacea and Glyceria maxima prefer eutrophic waters.

The classification of the Pszczynka River sections showed that the studied sections belong to three different classes of ecological condition. For homogenous fragments of the Pszczynka River an average value of MIR was 26.85 indicating, according to the adopted methodology, its moderate ecological condition. Diversified MIR values are the results of other tributaries to Pszczynka at its different fragments, the nearby neighborhood of dumping ground and roads, which is presented on Fig. 4. The sections located in the Krzyżowice village belonged to class II and III of the ecological status of rivers (based on their MIR values). The research sections in Warszowice on the other hand showed poor ecological condition, because this fragment is situated far from the tributaries of clean water from wastewater treatment plant and pumping stations. The relatively high value of the Macrophyte Index for Rivers at Krzyżowice section 3 (K3) (35.625), and hence classification of its ecological condition of water as good is most likely caused by the inflow of purified water from the pumping station located in front of this section. In contrast, the lowest value was found for the MIR at Warszowice section 2 (W2) (poor ecological status), due to the direct vicinity of a large area of fields and drainage ditches. A large impact might also have the direct discharge of water from the road and the Pszczyńska Street to the river. The value of Macrophyte Index for Rivers indicates the Class III of water quality in the Pszczynka River. The research performed by VIEP on the river fragment above the Meadow reservoir also classified Pszczynka as Class III of water quality. However, the value of MIR (26.85) obtained during presented studies in the area of the Pawłowice community is lower than the results given by VIEP (30.8). The further course of the Pszczynka River through agricultural lands causes its deteriorating ecological condition.

\section{Conclusions}

The Pszczynka River in the area of Pawłowice community presents a moderate ecological status and its water quality is classified as Class III. The ecological condition of the river, determined on the basis of occurring macrophytes is affected 
by: (1) tributaries of the fertilized waters coming from located in the vicinity of the river valley fields, meadows and post-mining wastes dumping grounds; (2) the inflow of water into the river from the existing technological equipment and facilities, such as pumping stations and wastewater treatment plants, furthermore by modification of the river bed (shifting, piled embankments) and as a result, the lack of conditions for the spontaneous formation of a shoreline vegetation. Considering the current, moderate assessment of the ecological condition, based only on the macrophytes, it seems to be possible to achieve a good condition, as required by the provisions of the Water Framework Directive by 2015 .

\section{References}

Bus A. 2010. Wstępna ocena stanu ekologicznego małej rzeki nizinnej na podstawie makrofitowej metody oceny rzek. Infrastruktura i Ekol. Terenów Wiejs., PAS, 9: 221-230

Czauderna M. 2011. Prognoza oddziaływania na środowisko projektu zmiany studium uwarunkowań i kierunków zagospodarowania przestrzennego w gminie Pszczyna. Bielsko - Biała, (manuscript).

Directive 2000/60/EC of European Parliament and Council from 23 October 2000 establishing framework for Community action in the field of water policy.
Gebler D., Szoszkiewicz K. 2011. Ocena stanu ekologicznego rzek z wykorzystaniem makrofitów na wybranych przykładach. Przegl. Nauk. Inż. Kształ. Środ., 52: 75-83.

Haury J., Peltre M.C., Treémolières M., Barbe J., Thiébaut G., Bernez I., Daniel H., Chatenet P., Haan-Archipof G., Muller S., Dutartre A., Laplace-Treyture C., Cazaubon A., LambertServien E. 2006. A new method to assess water trophy and organic pollution - the Macrophytes Biological Index for Rivers (IBMR): its application to different types of river and pollution. Hydrobiologia, 570: 153-158.

Janauer G.A. 2001, Macrophytes and the classification of the ecological status in rivers and likes. [in:] Classification of Ecological Status of Lakes and Rivers. Ed. S. Back, K. Karttunen. TemaNord, 584: 20-22.

Kondracki J. 2002. Geografia regionalna Polski. Wyd. Nauk. PWN, Warszawa.

Mirek Z., Piękoś - Mirkowa H., Zając A., Zając M. 2002, Flowering plants and pteridophytes of Poland a checklist. Inst. Botaniki im. W. Szafera. PAN, Kraków.

Pietruczuk K., Szoszkiewicz K. 2012. Zależność między klasyfikacją rzek opartą na makrofitach a jakością fizycznochemiczną wody na przykładzie rzek województwa wielkopolskiego. Ochr. Środ., 34: 41-46.

Prognoza oddziaływania na środowisko projektu aktualizacji Programu Ochrony Środowiska dla województwa śląskiego do 2013 z uwzględnieniem perspektywy do roku 2018. Katowice, 2010 (manuscript).

Stelmaszczyk R. 2007. Pszczynka pod stałym nadzorem. [in:] Jastrzębski Węgiel. Mies. Jastrzębskiej Sp. Węgl.

Szoszkiewicz K., Zbierska J., Jusik S., Zgoła T. 2010. Makrofitowa Metoda Oceny Rzek. Bogucki Wyd. Nauk., Poznań. 